Vol. 16, $n^{\circ} 1$ | 2012

Varia

\title{
Reporting Crime in the North of England eighteenth-century Newspaper : a Preliminary Investigation
}

James J. Sharpe

\section{(2) OpenEdition \\ Journals}

Electronic version

URL: https://journals.openedition.org/chs/1320

DOI: $10.4000 /$ chs. 1320

ISSN: 1663-4837

\section{Publisher}

Librairie Droz

\section{Printed version}

Date of publication: 1 May 2012

Number of pages: $25-45$

ISBN: 978-2-600-01594-3

ISSN: 1422-0857

\section{Electronic reference}

James J. Sharpe, "Reporting Crime in the North of England eighteenth-century Newspaper : a Preliminary Investigation", Crime, Histoire \& Sociétés / Crime, History \& Societies [Online], Vol. 16, $n^{\circ} 1$ | 2012, Online since 01 May 2015, connection on 23 March 2022. URL: http://journals.openedition.org/ chs/1320 ; DOI: https://doi.org/10.4000/chs.1320 


\title{
Reporting Crime in the North of England eighteenth-century Newspaper: a Preliminary Investigation'
}

\author{
James Sharpe
}

Cet article est une contribution aux travaux de plus en plus nombreux relatifs à la place consacrée au crime dans la presse du XVIII siècle. La majeure partie des travaux publiés sur ce sujet se sont concentrés sur la presse londonienne, ville où le problème criminel et la nature de la presse pourraient être différents de la situation en province. Il existe cependant une importante étude sur la presse provinciale, celle qu'Esther Snell a consacrée au Kentish Post. Il s'agit d'un travail de grande qualité qui fut à l'origine d'un certain nombre d'articles. Néanmoins, la lecture d'un certain nombre d'autres journaux provinciaux suggère une impression différente de celle produite par Snell, concernant le traitement du crime et la réaction qu'il suscitait chez les lecteurs. Le présent article s'appuie principalement sur le York Courant, un journal régional plus important que le Kentish Post, ainsi que sur d'autres journaux du nord. L'auteur soutient que le traitement de la criminalité y était généralement cursif et éloigné de tout sensationnalisme. Il examine également d'autres moyens imprimés d'information et conclue par une discussion de la fonction intégratrice de la culture des élites provinciales et nationales des principaux journaux provinciaux, et de la manière dont le thème criminel s'insérait dans ce dispositif.

This article is intended to contribute to a growing literature on newspaper reporting of crime during the eighteenth century. Most of the work completed on this subject has been focussed on London papers, where both the problem of crime and the nature of newspaper reporting may well have been different from the provinces. One important study of a provincial newspaper's crime reporting has, however, been completed, by Esther Snell, based on the Kentish Post. Snell's work is of a high quality, and has formed the basis of a number of published articles. But reading other provincial newspapers provides a different impression of crime reporting, and of readers' probable reaction to it, from that given by Snell. This article draws most of its information from the York Courant, a more important regional paper that the Kentish Post, and also draws on information from other northern newspapers. It argues that the reporting of crime in the York Courant was normally brief and far from sensational. The article also considers other ways in which people could be informed about crime from print culture, and ends by raising the issue of how the more important regional newspapers played a role in integrating

1 An earlier version of this paper was given at a conference on 'Letters before the law, 1640-1789', organised at the UCLA William Andrews Clark Memorial Library, 3-4 October 2008. 
provincial and national elite culture, and how reporting crime may have fitted into that process.

$I^{\prime}$ is now generally accepted that one of the most important developments in print culture in eighteenth-century England was the emergence of the provincial newspaper ${ }^{2}$. The way for the provincial press was cleared by the collapse of the Licensing Act in 1695, which broke not only the official licensing of publications but also the monopoly of London, the Universities, and York over the print trade in England. The value of news as a commodity was widely recognised ${ }^{3}$, and hence a number of printers in urban centres outside London experimented with what was a novel, and commercially risky venture - most of them regarded newspaper printing as one aspect of a broader range of publishing, and indeed other, activities ${ }^{4}$. The Norwich Post, first published in 1701, was probably England's first provincial newspaper, with The Bristol Post-Boy appearing in the following year, and both Exeter and Boston producing newspapers from 17045. As this list suggests, early provincial newspapers were concentrated south of the line between the Severn and the Trent estuaries, but by the mid-eighteenth century most towns in northern England and the north midlands enjoyed at least one newspaper ${ }^{6}$. Many of these early publications failed, prone to the normal vicissitudes of the market and the various stamp duties imposed on them, yet despite such difficulties provincial newspapers as a genre continued to flourish. By 1800 roughly 70 of them were published each week, some with a print run in excess of 2,000 copies. A total of 9.4 million newspaper stamps were issued in 1760, 12.6 million in 1775 , and 16.4 million ( 7 million for London papers, 9.4 million for provincial), in $1800^{7}$.

The totals of copies sold are only an imperfect guide to the scale of readership, and various multipliers have been suggested. In 1711 Joseph Addison proposed a minimum of twenty per copy ${ }^{8}$. What is certain is that the number of people who read a newspaper, or had a newspaper read to them, vastly exceeded the number of copies sold, and that this readership - and audience - went a fair way down the social scale. The centre of gravity of readership - and certainly that which the newspapers seem

2 There is now an extensive literature on the eighteenth-century English provincial newspaper. For the purposes of this article I have consulted: Cranfield (1962, 1978); Black (1987); Ferdinand (1997), which concentrates on the fortunes of The Salisbury Journal up to the middle years of the century. Although its focus is not that of this essay, I have also consulted Barker (2002), which summarises the arguments contained in Barker (1998) and Barker (2000).

3 For a discussion of this point in a slightly earlier period, see Fox (2000), chap.7, 'Rumour and news'.

4 This was certainly true of those responsible for publishing newspapers in York: Davies (1868); cf. Ferdinand's comment that 'the story of the English provincial newspaper press is closely associated with the book trade'. Ferdinand (1997, p. 5).

5 Cranfield (1962, p. 3).

6 Cranfield (1962, pp. 15-27) describes the expansion of the provincial newspaper over the first half of the eighteenth century.

$7 \quad$ Black (1987, p. 105); Barker (2002, p. 103).

8 Ferdinand (1997, p. 130), citing The Spectator 12 March 1711. Black (1987, p. 105), notes that other contemporaries suggested multipliers of between 5 and 40 . 
directed at - was the those social groups enjoying the new world of consumerism and gentility, which is currently regarded as characterising the upper third or so of Hanoverian society : the urban middle classes, both professional and mercantile, and the gentry and more prosperous farmers in the hinterlands of provincial towns ${ }^{9}$. But there is certainly evidence of a broader readership, both socially and topographically. In 1780 a writer in Lloyd's Evening Post, admittedly not an unbiased observer, could argue that "without newspapers... our country villager, the curate, and the blacksmith, would lose the self-satisfaction of being as wise [as] our First Minister of State' ${ }^{10}$. Very pertinent evidence on the importance of newspapers is provided by a blacksmith named Robert Robinson of Scalby in North Yorkshire, trying to establish an alibi when charged with highway robbery in 1775 . He claimed that he spent part of the afternoon in question bargaining over a horse, and then went to his father's public house where "there were six or seven people with me; they came to read the newspaper"11. By that date there was a sophisticated network for distributing papers. Newsmen would go out on horseback to take bundles of papers to towns and larger villages, dropping off copies to individual subscribers en route. On arrival, they would pass the bundles on to newsagents, who would sell or distribute them locally, and who might also act as local reporters, and through whom advertisements could be placed to appear in the newspaper they represented ${ }^{12}$. "Eighteenth-century provincial England", John Styles has commented, "was divided into a patchwork of overlapping newspaper territories"13.

The content of these papers varied over time. Early issues largely reproduced accounts of foreign and London-oriented political news culled from the main London newspapers, a process which has led the editors to be labelled by Bob Clarke as 'scissors and paste men' ${ }^{14}$. As Clarke comments, "the early provincial papers were local papers only in the sense that they were printed locally and contained local advertisements. There was no systematic attempt to cover local news and most early provincial papers had scarcely any local news at all"15. Throughout the century this interest in foreign and imperial affairs and central domestic politics was to remain of fundamental importance. But gradually the content of the provincial newspaper became more heterogeneous. Whether in response to an awareness of growing local identities, or in desperation when more important news was lacking, the newspapers began to offer more varied fare, notably 'country' news, which has been characterised as a "weirdly assorted collection of trivialities (...) sentimental and inconsequential

9 See the comments of Ferdinand (1997, pp. 131-134), for a thoughtful discussion of the Salisbury Journal's potential readership.

10 Quoted in Barker (2002, p. 102).

11 Williamson (1776a, pp. 4-5). Denied a newspaper, the company turned to playing cards, and a witness, Robert Anderson, told them how, when he subsequently went to the alehouse, "I took my news-paper with me, but seeing them playing cards, I did not take it out, but sat down by the fire".

12 For a full discussion of these issues, see Ferdinand (1997) chapter 2, 'The commercial structure of a provincial newspaper: Management and distribution'.

13 Styles (1989, p. 72).

14 Clarke (2004, p. 105).

15 Clarke (2004, p. 109). This was clearly the case with the first newspaper published in York, the York Mercury, which first appeared in 1718 under the editorship of Grace White, widow of the publisher John White, which "in the earlier years of its existence was composed almost exclusively of extracts from the London newspapers or news-letters". Davies (1868, p. 133). 
little items were very common indeed"16. These 'trivialities' often included very brief local news stories, and, as the century developed, provincial papers began to include details of the births, deaths and marriages of local personages, regular reports on local shipping, agriculture, and so on, as well as a wealth of advertisements dealing with local schools, cockfights, auctions, concerts and horse-racing. The 'trivialities' also comprehended reports, usually very brief ones, of crimes, both locally committed and from further afield.

The systematic use of provincial newspapers by historians of eighteenth-century crime is a development which is currently coming into its own. There have been some important pioneering works. In 1989 John Styles published a characteristically imaginative and soundly based essay on newspapers advertisements involving crime, a piece of special interest for this present article as it was based on an analysis of two northern newspapers, the York Courant and the Leeds Intelligencer ${ }^{17}$. Two years earlier Peter King had published an article on the reporting, and amplification, of a crime wave by the local press in mid-eighteenth-century Essex ${ }^{18}$. But a major breakthrough was signalled in 2007 when a number of articles on newspaper reporting of eighteenth-century crime appeared in a special issue of Continuity and Change ${ }^{19}$. One of the contributors to that special issue, Esther Snell, had in 2005 completed an important $\mathrm{PhD}$ thesis which analysed perceptions of violent crime in the eighteenth century through the lens of issues of The Kentish Post or Canterbury Newsletter published between 1717 and 1768, which is of special interest through its use of quantitative techniques ${ }^{20}$. The most salient of Snell's findings have been published, and it is to these that we will now turn ${ }^{21}$.

Snell argues vigorously for the importance of newspapers in shaping perceptions of, and discourses concerning, eighteenth-century crime. She contends that, as the eighteenth century progressed, newspapers became "the most significant source disseminating narratives of deviance" 22 in particular replacing crime pamphlets, and that "to understand attitudes to crime and responses to it in a local context it is crucial to understand the discourses circulating in the local press"23. She also suggests that "the newspaper was a participatory text, and that it, directly and indirectly, fostered an engagement and active participation by the reader" ${ }^{24}$. This engagement was particularly fostered by the focus which, on her reading, newspaper reports directed on the victims of crime. She identifies crime as being a vital element in the coverage of The Kentish Post. In the ten sample years for which she offers a detailed analysis of the Post's content ${ }^{25}$, there were a total of 56,093 reports, of which 14,721 concerned crime. The proportion formed by crime reports stayed fairly constant, although they

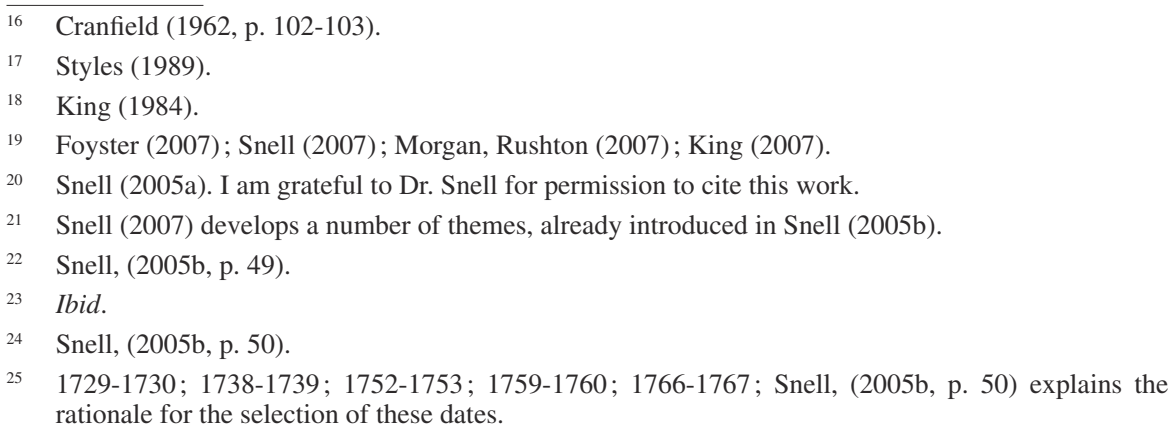


tended to drop in war years, when they might go as low as fourteen per cent. Most of these reports were concerned with crimes outside Kent, with items dealing with local crime varying between sixteen per cent of the total of crime reports in 1729 and thirty-seven per cent in 1738 and 1767. Snell is surely correct in asserting that reading about crime outside one's locality would still act as an influence on opinion and perceptions of crime, while, interestingly, she found that reports of local violent crimes outnumbered those of violent offences in other regions: on this evidence, "even the most heinous crimes" were represented as not just occurring far away but in locations close to the readers' lives ${ }^{26}$.

Snell's findings, to a large extent echoed by King's on London newspapers ${ }^{27}$, call out for comparisons based on other provincial publications : indeed, Elizabeth Foyster has suggested that "the typicality of the Kentish Post as a provincial newspaper would be worthy of study, and comparison with a newspaper that was printed outside the home counties may prove especially interesting" ${ }^{28}$. This article, albeit impressionistically, will attempt to meet this suggestion. It will be based largely on evidence from one of the most influential northern newspapers, the York Courant, supplemented by two newspapers published at Chester, the Chester Chronicle and Adams's Weekly Courant. Occasional reference will also be made to another significant northern newspaper, the Newcastle Courant. All of these papers were important regional publications. As the eighteenth century progressed, Newcastle became the most important centre for print culture outside London and the universities, and over the century supported more newspapers than any other provincial town, the Newcastle Courant being one of the most consistently successful of these ${ }^{29}$. The York Courant has been described as "one of the most powerful of all the county papers of the period" and as "one of England's most successful newspapers, enjoying and exceptionally large sphere of influence", a sphere which, in fact, covered a broad band of northern England between Scarborough and Manchester ${ }^{30}$. The Chester papers did not have the impact of their Newcastle or York equivalents. Nevertheless, Chester-based newspapers had an importance outside the city, and outside the county of Cheshire: thus Adams's Weekly Courant for 15 November 1738 carried advertisements not just for Chester and Cheshire, but also for Staffordshire and North Wales. As might be expected, all

$26 \quad$ Snell (2005b, p. 57).

27 King (2007); see also his important article which engages with the problem of how crimes reported in the capital were selected as newsworthy. King (2009).

28 Foyster (2007, p. 11). The point is borne out by Dyndor (2008) although unfortunately both the chronological and thematic focus of this piece restricts its usefulness to the issues discussed in this article. A wider investigation of the provincial press would also help balance the growing emphasis on crime reporting in metropolitan newspapers. Similarly see King (2007, 2009), and Landau (2010), which offers a critique of the interpretations of Snell and King. See also Devereaux (2007) and, for an earlier and broader study, Oldham (1987).

29 Berry (2005); McMillan (2006) also draws heavily on the Newcastle Courant. I am grateful to Mr McMillan for permission to cite his dissertation, and for his generosity in putting his research materials at my disposal.

$30 \quad$ Cranfield (1962, pp. 51 \& 202); Styles (1989, p. 72). 
four of the newspapers carried items relating to crime, and in particular references to violent offences occurred regularly, which will be the main focus of this article.

Perhaps surprisingly, the tone of some of these reports was light-hearted, especially so when the violence in question involved the lower orders, was nonfatal, and occurred at a safe distance from the place of publication of the newspaper reporting the incident. Thus the York Courant for 27 October 1741 ran the story of a fight in a tavern in Southwark, just across the Thames from the City of London, between members of a naval press-gang and the tavern's clientele. The sailors had entered the tavern in search of seamen they thought to be hiding in it, were faced by verbal hostility from those drinking there, started to use the staves with which they were armed, and were resisted by their opponents with "paring shovels, broomsticks, pokers, tongs, or any thing they could lay hold of". The report continued "in a word, the battle was presently general, and very bloody; here lay a taylor, there a sailor, and so on". This report contrasts with another carried by the same paper in its edition of 8 July 1740, described hyperbolically as "an account of the most notorious riot that ever happened in the memory of man". The issue here was a riot in Newcastle, when local colliers rioted in hostility to the export of grain from the area, and pulled down both Newcastle town house and the residences of a number of gentlemen supposedly involved in the grain trade. "Had it not been for the very lucky arrival of three companies of foot", the report continued, "it is thought there would not have been an exporters' house left standing" ${ }^{31}$. Thus "a sharp engagement between a press gang and a mob" in distant Southwark was the occasion for lighthearted treatment; rioting Newcastle colliers destroying civic and gentry property was quite another matter.

There was, however, a seriousness of tone in most of the reporting of cases of violence. This was especially true of those incidents where honest people, frequently drawn from the poorer sections of society, were subjected to attacks by footpads as they went about their business. Thus the York Courant of 7 September 1790 told how William and Ann Butterfield of Grimston were attacked as they walked home from York by six or seven men, who robbed them of a silver watch, a reward for which was announced at the bottom of the column where this crime report was published. Another report from the same paper's edition of 19 January 1790 reported that a York barber was stopped by two men a mile and a half from Whitwell, and robbed of $£ 4 / 4 /-$ : "they were both stout men, one near six feet high, in dark coloured great coats, round hats, and boots". Many of these accounts of attacks by footpads tell of the resourcefulness of the intended victims in evading or defeating their assailants. the York Courant of 6 November 1781 recounted one such tale. A young tradesman of Stockton-on-Tees was returning home from a visit in the country when he was attacked by three footpads, who took hold of his horse and ordered him to deliver his money: "but with his whip he bravely defended and disengaged himself, and clapping spurs to his horse, arrived safe at Stockton". Yet even with a relatively happy outcome, such reports helped reminding readers of the dangers of crime in their locality.

But it was of course the reporting of murder which set the tone for accounts of crimes of violence. It is here perhaps that we can see the most marked changes in reporting over the eighteenth century. There were some relatively full accounts early

$\overline{31}$ The Newcastle riots of 1740 were indeed a very serious occasion of mob action: see Ellis (1980). 
in the century, but murder was frequently treated like any other of the short reports carried in the 'country news' section of the newspaper. A typical example comes from a Chester newspaper of 1731:

Nantwich, Oct 4. Last Friday a very unhappy accident happen'd here, two butchers scalding a swine, the one in a jesting manner threw a little water at the other and so provok'd him, that he said 'If he did not give over he would fling his knife at him', which being repeated again exasperated him so that he darted his knife at him and it went between his ribs, who said no more words than 'Thou hast done my business now', he pluck'd out the knife himself and blood gush'd forth in such a manner that he died immediately.

This simple account of male-on-male violence, devoid of comment apart from being described as "a very unhappy accident", appeared between an account of a woman who had been run over and probably fatally injured ("tis tho't she cannot live") by two boys horse-racing, and another about a doctor, with a visit to Chester impending, who had reputedly cured a number of deaf and blind people in Edinburgh ${ }^{32}$. Although as the century progressed, at least some newspaper accounts of murder became lengthier and more complex, this style of crime reporting, as we shall see, proved persistent.

Reports of murders where the perpetrators of the crime had not been caught were probably especially unsettling. One such was carried by The York Courant for 31 August 1790, involving the killing near Boston in Lincolnshire of Susannah Watts, a girl aged about seventeen, who "was most inhumanly murdered by some persons as yet unknown". Watts had left the household where she was a servant to visit her parents, and was discovered near her master's house by some horsemen, "weltering in her blood; her head nearly severed from her body supposed to be done by a reaper's hook". One of her pockets was turned inside out, and the "inhuman villain" had taken away eight pence in money, a pair of oval plated buckles, and a pair of white cotton stockings. The reader was assured that "very proper exertions are making [sic] by the magistrates to discover the perpetrator of the barbarous deed". On 21 January 1793 the York Courant described another incident of violent death in which the killers had yet to be identified. This was a report of a coroner's inquest at Leeds on the body of sixty-five year old William Pierson from North Bierley near Bradford. He had been to market in Leeds, had visited relatives there, but at 10 p.m. on the night in question had been found "expiring", thrown into a small pond. His pockets had been emptied of their contents, and given this and the fact that he had "marks of violence about him", the jury brought in a verdict of wilful murder by person or persons unknown. The report ended by the writer stating "we hope the inhumane wretch or wretches will, ere long, be discovered, and receive the punishment that justly awaits such horrid barbaritie".

The theme of murder by killers unknown extended to infanticide ${ }^{33}$. As one of the major serious female offences of the century, instances of infanticide were noted

32 Cited in Clarke (2004, p. 112). A coroner's inquest and indictment relating to this case survive in the relevant roll of the Chester Court of Great Sessions: The National Archives, London (hereafter TNA), CHES 24/157/4/1. This documentation confirms the newspaper account. The killer was named James Hall, his victim Thomas Parker. Hall was found guilty, but no details of punishment are given.

33 The standard work on infanticide in this period is Jackson (1996), which draws heavily on Northern Circuit assize materials. See also Dickinson, Sharpe (2002), 
fairly frequently in the newspapers, although they were rarely discussed at length. There were also occasional reports of the bodies of newborn children being found whose killers remained unknown. The Chester Chronicle of 14 March 1775 reported the discovery of "a new-born man child, wrapped in an old apron and a sheet, with a stone near 14 pounds weight laid on its breast", which was discovered in a small rivulet running through Macclesfield. "The most diligent enquiry", readers were reassured, "is making after the person who committed this shocking act of cruelty". In the following year, the issue of the same paper for 6 September told how some children who had been playing in a churchyard in Chester found "a small box that had been concealed under a few sods", in which was found the body of a child. The coroner's inquest on this occasion brought in a verdict of still born. These occasional reports of the finding of the bodies of dead new-born children reinforce the suspicion that cases of infanticide which were prosecuted were only a small proportion of those actually committed.

Some murders, of course, were more newsworthy than others. One such came in 1767, when the York Courant for 11 August reported the execution of Anne Sowerby, who had poisoned her husband, and who, after being drawn to York Tyburn on a sledge in the prescribed fashion, was burnt to death for petty treason ${ }^{34}$. Just before she was brought out of her cell before execution, she confessed the crime, saying that she did it with the encouragement of a John Douglas, who had poisoned his own wife. She had burnt the first batch of poison that he had delivered to her to kill her husband, but she subsequently accepted some arsenic from him, and Douglas "assisted her in mixing it with curds which she gave her husband for breakfast, who died after eating them". The reader was reassured that "she acknowledged the justice of her sentence, and died penitently". As ever, the execution of one of the gentry for murder was especially newsworthy. In an execution report, in this instance from the York Courant of 10 April 1781, we read of the last moments of the "unfortunate gentleman" William Meyer, Esq., aged thirty-three, who had shot a certain Joseph Spink with a pistol. Meyer was transported to York Tyburn in a mourning coach, accompanied by a clergyman and the city gaoler. After praying at the gallows, he "discoursed very much with the under-sheriff who was presiding at the execution, telling him that the shooting was accidental", and "He likewise conversed about his estates, and family, particularly mentioning in what manner he should wish to have his son educated, and recommending certain persons as trustees for his offspring". He then "harangued the spectators for a considerable time", and was then executed "in the sight of a numerous concourse of people". His body was subsequently put in a hearse, and taken away for dissection at York hospital ${ }^{35}$.

Such accounts, despite the special interest furnished by the social status of the person being executed, were standard. But it is possible, perhaps rather unexpectedly, to find reports where the psychological condition of the murderer is at the centre of interest. One such involved the execution of at York of William Atkinson, as reported in Adams's Weekly Courant of 26 May 1771. Atkinson apparently told a Mr Wharton, presumably a minister, that:

On this practice, see: Campbell (1984); Devereaux (2005).

35 The public dissection of the corpses of all of those executed for murder was enacted by a statute of 1752, 25 Geo. II cap. 37, with a deterrent intention: although provincial reactions have yet to be studied, the practice engendered considerable hostility among execution crowds in London: Linebaugh (1975). 
He had, without the least provocation, for three weeks before the perpetration of the murder, several times a strong inclination to commit it; but had always got the cruel thought driven from his mind, till the unhappy night in which he effected it, when he went to bed, but could not rest; that he got up and fell to prayers, in hopes of diverting these thoughts; but so irresistible was the impulse, that he at last went into the house of William Smith, armed with a mattock and hatchet, broke open the door with the mattock, and found him asleep in bed, where he struck him several times on the head, but whether with the mattock or hatchet he could not remember; and that afterwards he took the deceas'd's purse, containing one half guinea, a quarter guinea, about five shillings in silver, and six pence in copper.

Although extremely unusual, this account does show a willingness to report the psychic struggle of what was, one suspects, a mentally disturbed killer. Such reports were unlikely to have been written at any previous point, and the description of William Atkinson's inner struggle does point to new ways of thinking about murderers in the later eighteenth century ${ }^{36}$. It is also noteworthy that the newspaper also reported that the relevant York assize had also sentenced eight other people to death, all for property offences: their stories were evidently not as noteworthy as that of this most remarkable murderer.

Crimes of sexual violence were, as Snell discovered with her Kentish study, comparatively rarely reported ${ }^{37}$. Perhaps the most vividly described comes from the York Courant of 10 April 1781. It followed the execution at York Tyburn of Joseph Linwood who had robbed Margaret Lee of Huntington (a parish just outside York) on the highway. The report tells us that:

Not satisfied with taking the woman's property, he used every argument, every threat to force her compliance with his desires. Finding himself so strongly opposed to obtain his wish, he took her by the feet and dragged her for a considerable way on a plowed field, adjoining to the road which leads to Huntington, till her clothes were almost torn off, and himself out of breath. He exercised more cruelties than this, but finding them equally abortive, he at last asked her if she knew him; but being answered in the negative (tho' at the same time she perfectly recollected him, yet afraid to confess it) he permitted her to depart. This conduct the judge looked upon at his trial in as bad a light as the robbery.

Linwood, in the best traditions of the eighteenth-century execution narrative, died resigned to his fate, acknowledged the justice of his sentence, "and was extreamly intent and deliberate in his devotions". The report recorded that he was aged twentyseven, "and has left a widow and three small children".

But most cases of sexual violence received much shorter treatment. The committal of accused rapists was occasionally noted, but there was little by way of extended discussion ${ }^{38}$. Perhaps the most detailed account was carried in Adams's Weekly Courant for 10 May 1768, relating to a rape committed at Gosport. It concerned the rape of a fourteen-year-old girl by Anthony Thorner, a sailor in the

36 Adams's Weekly Courant of 3 September 1771 contains an account of another individual suffering from inner turmoil, William Reynolds, who committed suicide despite the best efforts of a clergyman. The newspaper's tone is, however, unsympathetic to Reynolds, and the report told how his corpse was eventually buried at "an obscure cross lane".

37 Snell (2005b, p. 59).

38 E.g., the committal to Exeter gaol of three soldiers suspected of having raped a woman on the road between Crediton and Sandford reported in Adams's Weekly Courant for 29 March 1768. 
Royal Navy. Thorner encountered the girl in a lane as she was fetching the cows for milking, and "threw her down and ravished her". Her cries were heard by a farmer in a nearby field, who brought a dog with him, and came across Thorner as he was "going to repeat the action". The farmer and his dog chased Thorner, and caught and overpowered him. Perhaps the fullest discussion of a rape case so far discovered in these sources came when Adams's Weekly Courant of 11 September 1750 reported on what was presented as a case of false accusation. It reported an indictment at Bristol Assizes against a captain John Dalliner for the alleged rape of Jane Smith, "which was thrown out by the grand jury". Undeterred by this setback, Smith or those supporting her decided not to let matters drop:

Another bill was thereupon preferr'd against him, for assault with an intent to ravish her, which was met with the same fate, there appearing no foundations for these prosecutions; what is a very great hardship on the captain, who has been imprison'd on this account upwards of eight months. And we are inform'd that actions at law will be commenced against the person's concern'd in the above prosecution.

The newspapers also carried occasional accounts of a type of rape which evinced immediate obloquy, that involving small children. Hence Adams's Weekly Chronicle for 8 March 1791 reported the coroner's inquest at Manchester on Jane Hampton, "a poor child, under four years of age", who had died after sixteen-year-old James Wray had attempted "to have the carnal knowledge of her body". Wray ("the villain") had escaped.

\section{III}

Despite the odd instance where a murder or other offence was described at length, most of the narratives reporting violent crime in these northern newspapers were surprisingly short and unsensational. In contrast to the sometimes very rich accounts of murders and other serious crimes contained in Elizabethan and seventeenthcentury pamphlets ${ }^{39}$, these eighteenth-century newspaper stories seem very brief and rather flat. There are indeed numerous references to crime in eighteenthcentury newspapers, but most of these come in the form of advertisements aimed at recovering stolen property, or in brief accounts of prisoners committed or tried at the local assizes and quarter sessions: the York Courant was already listing those tried at the assizes by the late $1730 \mathrm{~s}^{40}$. It is difficult to assess the impact of these latter. The York Courant adopted a standard approach to its coverage of the assizes, normally providing a list of those awaiting trial and also a list of grand jurors, which it seemed to think was a matter of some significance to its readership. In the issue after the assize took place, a brief note would be given of the fate of all of those appearing there. By the late 1780s this coverage of the assizes was accompanied by reports from local quarter sessions, and, indeed, from other assizes. This may have had the effect of creating an image of a widespread crime problem, but the reporting was uniformly matter-of-fact and unsensational, while the content of these reports was frequently unlikely to cause too much concern. The news that three thieves, a

\footnotetext{
39 For a work based on these materials, see McMahon (2004).

40 Perhaps the most noteworthy of these was Dick Turpin, executed at York in 1739: The York Courant, 10 April 1739.
} 
purse-snatcher, and a man who had assaulted a parish constable had been tried at the Summer North Riding sessions at Easingwold was unlikely to promote fears that the fabric of society was under threat, while the news that that "at the Rutland assizes there was not a single cause entered nor any prisoners to try" was positively reassuring ${ }^{41}$.

There are, moreover, occasional scraps of evidence that crime was not regarded as being especially interesting by at least early eighteenth-century readers. In 1732 the owner of the Derby Mercury began to print "the most remarkable trials at the Old Bailey", but had to discontinue the practice when a number of his readers wrote to him complaining that these accounts were taking up too much space, to the detriment of the news they wanted to read ${ }^{42}$. The first editor of the Northampton Mercury, when it was first published in 1720, made a conscious decision not to include crime news, but to concentrate on the reports of politics and foreign affairs, which he thought would be the main preoccupation of the upper-class readership that he aimed at attracting ${ }^{43}$. The Newcastle Courant of 1 March 1735 justified printing details of an execution in London on the grounds that it had not "been hitherto made public in these northern parts", and - giving an interesting insight into editorial priorities - that in any case "news this week is very barren" ${ }^{4}$. Things had changed by the later eighteenth century, but even then accounts of serious crimes were hardly filling the columns of the newspapers under consideration in this article. In 1772 the Newcastle Courant began to publish a section entitled 'Hue and Cry', in which advertisements for stolen goods containing their previous owners' accounts of how the goods in question had been stolen, thus adding short crime narratives to the staple diet of crime advertisements. This at first looks like evidence of an increased interest in crime, but, as a student of the paper in question has commented: "Thus the Newcastle Courant filled its quota of crime narratives in one profitable section and the rest of the publication was relatively devoid of criminal matter after this" ${ }^{45}$. Newspaper editors knew that there was an interest in crime, and that it was the more sensational cases which were worth reporting: but the sensationalism in these late eighteenth-century narratives was pale compared to that overtly sensationalist approach to newspaper reporting of crime which arrived in the nineteenth century and which is still very much with us $^{46}$. Moreover, what was considered newsworthy sometimes created some anomalies. A report that a Mr Gill of Notton, "a gentleman of considerable property" had been convicted at the West Riding quarter sessions "for selling beef that was unfit for use" was given as much space in the York Courant as were many murders ${ }^{47}$.

Indeed, the frequently brief descriptions of serious crimes were sometimes jumbled in with other accounts of accidental deaths or other misfortunes, which

\footnotetext{
$41 \quad$ York Courant, 26 January 1787; 20 March 1787.

42 Cranfield (1962, pp. $72 \& 75)$.

43 Dyndor (2008, p. 181).

44 One might also note Peter King's comment that (in the revolutionary period) "when the news from France was especially exciting, for example, editors would almost certainly have cut down on the number of trial reports they published" (2009, p. 95).

45 McMillan (2006, p. 54).

46 For a very pertinent study of sensational crime reporting in the nineteenth century, see Curtiss (2002).

47 York Courant, 26 January 1787.
} 
suggest that this reportage was not so much aimed at creating fear of crime but rather, probably unconsciously, left the impression that crime was an unfortunate occurrence which came to individuals as did so many other unwelcome events. A number of reports in the York Courant for early 1797 illustrate this point. There was one account of "a most shocking murder" in Staffordshire, in which an apothecary surnamed Oliver had shot and killed a Mr Wood, and was then narrowly prevented from shooting himself, the cause of this incident being that Wood had blocked Oliver's courtship of one of his daughters. There was also a report of a girl aged four being found in Hull docks with her throat cut, a wound from which she soon expired. These reports were juxtaposed with brief accounts of other fatalities: one at Hull docks where a man working there received fatal injuries after being knocked into a ship's hold by a piece of wood; another from Hull describing how a woman sitting in front of a fire was seized by a fit, fell into the fire, and in the absence of any help "was burnt in a most dreadful manner, and expired the next morning in the most excruciating agonies"; and yet another from Hull, in which a boy named Boothby, "in consequence of a quarrel with one of his friends, on account of his not going to church, took a quantity of mercury, and died the next day". Thus the brief accounts of murder and other serious crime in the newspapers would seem to be just part of a distinctive aspect of contemporary reporting, rather than representing a distinctive picture of contemporary crime ${ }^{48}$.

This impression of the essentially non-sensationalist reporting of crime is confirmed by a close scrutiny of the York Courant's crime reporting in a sample year, 1790. There were a few sensational crimes which were given brief reports. We have already encountered the cases of Susannah Watts and William and Anne Butterfied ${ }^{49}$, and a number of other violent crimes were described, murders included ${ }^{50}$. But such cases probably averaged less than one a month. Similarly, by this point the Courant was rarely reporting crimes, however sensational, from outside Yorkshire. Thus the two cases which, according to Peter King, attracted most attention in the London press in 1790, that of the Aldersgate Street arson case and that of William Renwick, 'the Monster', attracted no reports in the Courant, although pamphlets describing both these cases were advertised there, evidence of the enduring influence of this type of publication ${ }^{51}$. There were occasional advertisements concerning stolen horses, or, more frequently, horses described as lost or stolen, and of suspicious persons, but, again, these were probably not of either a quantity or quality to provoke respectable fears. Reports of prisoners committed to the county gaol at York Castle or York city's Ousebridge gaol appeared regularly, but were short, and appeared in a column which consisted mainly of reports of births, deaths and marriages as well as local society balls ${ }^{52}$. A case where a bear kept for bear-baiting escaped and savaged

48 York Courant, 6 February 1797; 13 February 1797; 20 February 1797. The report of the murder in Staffordshire came via the Derby Mercury.

49 York Courant, 31 August 1790; 7 September 1790.

50 E.g., York Courant, 23 February 1790.

51 King, (2009, p. 92 \&101); York Courant, 10 August 1790; 9 November 1790.

52 It is interesting in this context to note the comment from 1780 by a clergyman, William Jones, that due to the numerous reports of executions in the newspapers, "their frequency makes them less shocking and terrible, and a list of poor wretches launched into eternity is now read by many with as much indifference as if it were a list of births or marriages": cited in Gatrell (1994, p. 282). 
a woman received more space, and more moral comment, than any of the murders reported that year ${ }^{53}$.

Thus although newspapers undoubtedly provided the most important print source for information about crime, what exactly that information was meant to convey and how exactly it was interpreted by the reading public remain problematic. It should also be remembered that the newspaper was not the only print medium through which information about crime was conveyed to the reading public. Crime pamphlets $-\mathrm{a}$ relatively under-researched source for this period - continued to be produced, and contained considerably more information than newspaper reports and devoted ample space to moralizing ${ }^{54}$. Newspaper accounts were far shorter, and were usually devoid of any moralizing; indeed, Jeremy Black, in his overview of the eighteenth-century English press, has commented on how the newspapers of that period more generally contained less relating to religion than might have been expected ${ }^{55}$. Certainly, the moral universe within which crime reporting took place in the eighteenthcentury newspaper was very different from that traditionally offered by the murder pamphlet ${ }^{56}$. It is unknown if there was much of a readership in northern England for that major source upon which opinion about crime, or at least metropolitan opinion about crime, was formed, the Proceedings of the Old Bailey ${ }^{57}$. In the 1770s, however, readers in York at least were offered a local equivalent in the form of reports of 'trials at large' at the assizes provided by a shorthand expert from London, William Williamson ${ }^{58}$. These publications, which rapidly dropped in price from a shilling to $6 \mathrm{~d}$, offered the local reading public a full account of what happened in trials at the York assizes. That covering the Lent 1776 assizes, for example, contained full details of the trial of a number of alleged murders. Lawrence Harvey of Easington was accused of the murder of his apprentice, Mary Nowell, aged nine. Readers were offered very detailed evidence from the doctor who examined her, witnesses in the community, and the girl's mother (young Mary was a parish apprentice) ${ }^{59}$. And, more sensationally, Thomas Aikney was tried and convicted, along with his lover Elizabeth Boardingham, for the murder of Elizabeth's husband John Boardingham of Flamborough. Again, the trial was described in full detail, as was the sentence against Elizabeth Boardingham, to be burned for petty treason ${ }^{60}$. Such accounts

York Courant, 21 December 1790.

54 As in earlier periods, most of these pamphlets were published in London and dealt with crime in the metropolitan area. For some very rich Yorkshire examples, see Anonymous (1749); Anonymous (1753); and Anonymous (1774).

55 Black (1987, p. 248).

56 An issue discussed by Snell (1995b, p. 66).

57 A source recently discussed in Shoemaker (2008).

58 It is unclear if surviving examples are all that remain of a more extensive run, or if this publication indeed only appeared in the mid-1770s; extant examples include: Williamson $(1775,1776 \mathrm{a}, 1776 \mathrm{~b}$, 1777). The last of these publications, and Williamson's wider expertise as a teacher of shorthand, were noted in the York Courant, 18 March 1777.

59 Williamson (1776a, pp. 17-22).

60 Williamson (1777a, pp. 25-29). This case provides a good example of how this type of printed account can be followed through in official documentation, with both the coroner's inquest on Boardingham and the relevant indictments being preserved (Elizabeth Boardingham's is marked 'guilty, to be burnt'), and also the execution being noted in a Northern circuit assize minute book; TNA, ASSI 44/91 Part 1; ASSI $41 / 7$ (Northern Circuit Minute Book 1775-1788), unfoliated, York Assizes 9 March 1775. 
would have had much more impact than the standard newspaper report. The public could also read printed gaol calendars, which were probably displayed in taverns and coffee houses, and might well have formed the basis of the list of felons to be tried at the assizes which, as we have noted, appeared in the York Courant. These usually provided more information than that given in the newspaper, with information on the case roughly equivalent to that given on an assize indictment, and details of the relevant committing justice ${ }^{61}$. Ballads were widely circulated, and included crime and punishment in their subject matter ${ }^{62}$. Single-sheet broadsides, like ballads selling more cheaply than newspapers and hence perhaps more likely to be read by the poor, and many of which dealt with crimes and executions, were to survive well into the nineteenth century ${ }^{63}$. Thus newspapers may have been the main source of printed information about crime, but they were certainly neither the sole nor the fullest such source.

\section{IV}

There is also a need to consider the broader objectives of those who published newspapers, other than the simple desire to make money. Some interesting pointers here have been suggested in a thought-provoking article by Helen Berry ${ }^{64}$. It has generally been accepted that one of the functions, deliberate or otherwise, of the eighteenth-century English provincial newspaper was to break down regional isolation, and help the processes of national integration. The dependence of provincial papers on London news, which in any case diminished as the eighteenth century progressed, masks a relationship in which newspapers operated not as passive consumers, but rather as agents in a two-way process of communication between centre and peripheries ${ }^{65}$. Thus in what was a far from unique case, by 1740 the York Courant was available in a number of London coffee-houses, had a permanent correspondent in London, and accepted London advertisements for publication ${ }^{66}$. The role of newspapers in aiding political integration has long been acknowledged, notably through the work of Hannah Barker ${ }^{67}$. But what Berry, concentrating on Newcastle publications, has argued is the importance of newspapers in fostering cultural integration between the values of the metropolis and those of a regional

${ }_{61}$ For example, Anonymous (1776). Interestingly, by the late eighteenth century these printed calendars had replaced the traditional manuscript parchment calendars as wrappers for the documents contained in each assize file: e.g. TNA, ASSI 44/92 part 2; an earlier example is provided for the file for a meeting of the Court of Great Sessions at Chester in 1742, which has a printed 'Kalandar' of prisoners awaiting trial at Chester castle as a wrapper: TNA, CHES 24/161/3.

62 Ballads and crime form the basis of a number of the essays in Fumerton, Guerrini, McAbee (eds.), (2010). Nineteenth-century collections suggest the existence of a lively ballad culture in eighteenthcentury Yorkshire: C.J. Davison Ingledew (1860); Forshaw (ed.) (1892).

63 For an analysis of this material see Gretton (1980); the contrast between the treatment of crime in these broadsides and newspapers is discussed in Dyndor (2008).

64 Berry (2005).

65 This point is illustrated in a lengthy and very pertinent discussion by Hannah Barker of how the political controversy surrounding Christopher Wyvill's campaign for parliamentary reform was handled by the York newspapers: (1998, pp. 138-174).

66 Black (1987, p. 57); Clarke (2004, p. 117). Berry (2005, p. 9), notes similar connections for Newcastle newspapers.

67 E.g., Barker (2002). 
capital and its elite. London, she argues, set the standard. But she is insistent that the Newcastle elite was not simply a passive consumer of London taste and London fashion. She suggests that "in elevating certain cultural activities and patterns of consumption as tasteful, Newcastle newspapers participated in the construction of an idea of polite, "national" society in which the North East participated fully", and that as a result of that participation Newcastle newspapers "created a distinctive and influential regional platform for the exchange of ideas about cultural value in the eighteenth century"68. Thus although, as Berry puts it, "we may in part see the local press as an organ for those who were investing in promoting the idea of a "national society' in the North East" ${ }^{\prime 69}$, the acquisition of this idea could, paradoxically, result in a strengthening of regional elite culture. So there was, as we have noted, growing space for local news, in Newcastle's case especially news relating to the town's 'summer season' of cultural and social events.

Reading the newspapers produced in York and Chester likewise conveys a sense that they were being produced for an ever more economically developed and culturally sophisticated provincial society where the values being promulgated from the centre were being absorbed, but were also being tempered by and adapted to local needs. The transition can be demonstrated by analysing two chronologically distant editions of the York Courant. The content of the first, one of the earliest extant editions, no.173, published on 31 December 1728, consists largely of foreign news and London-based political news reprinted from two editions of the London Evening Post, including what I take to be an abstract from the London Bills of Mortality (among the deaths, chillingly, were listed 'Teeth 32'). This filled nearly all of the four pages of the newspaper, slightly less than a column being devoted to other items, of which there were three: an advertisement for a bookseller in York, and advertisement for the recovery of stolen goods, and a notice about tithes in three parishes near York. This can be contrasted with the edition of 17 April 1781. Foreign news filled a column and a half on the first page, while page two was largely devoted to national politics as played out in London. The remainder of the paper was filled with variegated matters, including a notice of the annual Doncaster Florist [i.e. Floral] Meeting, a Grand Concert to mark the annual music festival in the same town, a meeting of the East Riding Agricultural Society, an advertisement for a boarding school for ladies at Scarborough, and an advertisement for a free school near Northallerton. News for York itself included a notice of a forthcoming charity sermon at the lunatic asylum, an advertisement from a local firm who wished to "respectfully acquaint the public, that they have now on sale an assortment of fashionable silk for the Spring and Summer seasons", and an advertisement for day trips in "a diligence" between York and Carlisle. Reports of crime had to compete for publication with a lot of other newsworthy material in the late eighteenth-century York Courant.

Provincial newspaper owners were certainly aware that they were living in a world where taste, politeness, civility and rationality were the hall marks of a fully civilised human being. Consider the justification for continuing to purchase the publication given in 1797 in another important provincial newspaper, the Stamford Mercury, when a hike in stamp duty aimed at helping to fund the war against revolutionary France resulted in a rise in the Mercury's price:

\footnotetext{
68 Berry (2005, pp. 3 \& 14).

${ }^{69}$ Berry (2005, p. 6).
} 
To live in ignorance of passing occurrences will not be borne in an enlightened nation, especially when it is considered that such a species of ignorance would absorb every noble faculty of thought and investigation, and reduce us to a state of barbarity. Without information, we are the mere slaves to appetites and passion; and to give general scope to such information, weekly publications have been planned thereby, through cheapness compared with the vast weekly expense of the daily press, enabling all ranks of people to obtain $\mathrm{it}^{70}$.

One is reminded of Berry's comment that reading the Newcastle newspapers could in itself "be construed to be a mark of discernment that gave the reader claims to being informed about current affairs at the local, regional and international level"71. On this reading, and on the claims put forward in 1797 in the Stamford Mercury, the provincial newspaper was determined, and probably successful, in ensuring that the eighteenth-century values of politeness, restraint, rationality, and taste should be promulgated in the area from which it drew its readership, those very values which were recognised as signifying that England was an "enlightened nation".

Where does the reporting of crime in these provincial newspapers fit in with this ideological and cultural thrust - located as it was between the providential framework of the seventeenth-century murder pamphlet and the sensationalism of the Victorian popular press? Evidently, most people committing crimes, especially the crimes we have been mainly concerned with here, stand up badly as polite and rational human beings, replete with taste, civility and enlightenment values. But the way in which their activities were reported were unlikely to have struck terror into those who did aspire to such values. Obviously, the reporting of crime might encourage respectable fears, and the reporting of local crime would have even more of an effect; as one writer has put it, "no longer was Covent Garden the centre of deviancy" 72 . But for the most part, although the reality of crime was recognised, it was kept on the margins, largely retained in the almost routine areas of advertisements for the recovery of stolen goods and the brief listings of felons who were awaiting trial or who had been tried at the assizes.

Conversely, some of the more detailed accounts of crime and punishment were reflecting the rhetoric of the new cultural standards. Let us consider the description given in Adams's Weekly Courant for 26 April 1791 of William Henry Clarke, alias Lowndes, Lowin or Hope, who was executed at Chester for robbing a mail coach eight years previously:

Never were the feelings of the multitude so much interested as they appeared to be when his wife and brother attended the cart, to take a last, a long farewell. The sympathetic tears rushed from almost every eye, when the unhappy pair were taking their parting embraces! For a while, his crimes were forgotten - the scene was too affecting; but then reason interfered, and it was considered, that justice demanded that life, which it was evident he had made too criminal a use of.

Clarke assured his wife that "he hoped they should meet in a far better place", and told his brother to leave, as it would all be too upsetting if he stayed. The account continues:

He wept almost continually, at the same time praying for forgiveness at the throne of mercy. He exhorted the spectators to put their trust in God, intreating them, as

\footnotetext{
$70 \quad$ Newton, Smith (1999, p. 74).

71 Berry (2005, p. 6).

72 McMillan (2006, p. 56).
} 
they valued their precious souls, and regarded the welfare and happiness of their offspring, to bring them up in the paths of religion and virtue; at the same time declaring, that he had not wanted for advice and good example to have prevented his ignominious end. He was not 34 years of age; and it is suspected, had long committed depredations on the mails. It is supposed, the expence of apprehending and prosecuting him cannot be less than 20001 [i.e. $£ 2,000$ ]. His body now hangs in chains on Heltby Hill, near Frodsham.

There is, of course, much here that would have not been out of place in an execution pamphlet of a century, or even two centuries, earlier. But there is relatively more emotion, relatively less religion, and, perhaps above all, it was 'reason' which intervened to move the ritual of execution forwards. The edition of the same newspaper for 7 September 1790, indeed, provides evidence of how the values of eighteenthcentury politeness and civility were entering the courtroom. John Dean was found guilty of murdering his wife, and was convicted, so the paper tells us, "on the clearest evidence of very respectable witnesses, particularly that of Mary Bell, Mr Thorneby, the constable from Stockport, whose conduct and humanity on the occasion the judge very highly applauded", and also of Mr Clark, "the surgeon, who opened the body". We are clearly in a more measured world than that obtaining a century before.

There is also the underlying problem inherent in the term 'the Provincial Newspaper', whose adoption may well obscure differences within the genre. Although all eighteenth-century English provincial newspapers shared some common features, we should perhaps think of their potential differences: their political position (the York Courant and the Chester Chronicle were identified as Tory publications ${ }^{73}$; differences in editorial style; and the nature of the territory covered. As Snell makes clear, the influence of the Kentish Post was bounded by the sea to the south and the east, and by the influence of London publications to the north and west $^{74}$, and hence would not have the regional importance of the York Courant or its Newcastle equivalents ${ }^{75}$. Editorial policy was another complicating factor. James Abree, the Kentish Post's publisher during the period that Snell deals with, seems to have made much heavier use of the London journals than did his counterparts in York, Newcastle or Chester: we return to Elizabeth Foyster's concern over the typicality of the Kentish Post ${ }^{76}$.

There remain some reservations. Although we might accept that the newspaper was the medium through which most people received most of their information about crime, there is still the largely unreconstructable issue of the oral transmission of information about the subject ${ }^{77}$. More certainly, the initial analysis of these northern

73 Cranfield (1962, p. 126).

74 Snell (1995b, p. 51).

75 It should be noted, however, that Snell is emphatic that the regional newspaper "was not merely a parasitical clone of the London press": (2005a, p. 274).

76 Foyster (2007, p. 11).

77 Odd pieces of evidence about oral transmission of ideas about crime can be suggestive. To take a well known source, albeit from an earlier century, Samuel Pepys's recording of how news of the robbery of a Mr Tryan early in 1664 is instructive. Pepys found out about the case on 8 January 1664 through "a great talk" at the Stock Exchange; he then discussed the case at a dinner party with friends at his home the following night, by which time a Colonel Turner was suspected, and a few days later found that "the general talk of the town" was still about the case. He heard that Turner had been found guilty through gossip at the exchange, attended his execution on 21 January, and afterwards "thence to the coffee house and heard the full of Turner's discourse in the cart", all of these before a word about the 
newspapers leaves the reader less convinced than Snell about the pervasiveness of crime reporting in the eighteenth-century provincial press, and thus on her conclusions on how worrying the reading public found newspaper reportage on crime. As I have suggested, my reading of the northern newspapers consulted for this paper suggests that although crime reporting was certainly there, most of it was relegated to the very routine matters of advertisements for the recovery of stolen goods and the very brief reporting of those committed to the local assizes and what subsequently happened to them. Some time ago John H. Langbein achieved notoriety by suggesting that although crime was a matter of concern in the eighteenth century, it was a matter of concern on a level with garbage collection ${ }^{78}$. While I am unwilling to go thus far, Langbein's analysis does raise questions as to exactly how significant worry about crime actually was in the eighteenth century ${ }^{79}$. In particular, reading these northern newspapers has also left me unconvinced of the emerging orthodoxy that eighteenth-century newspaper reporting of crime put a new emphasis on the victim $^{80}$. Many descriptions of crimes did indeed focus on the victim's experience, but unless the perpetrator was unknown, the criminal as well received a fair share of attention ${ }^{81}$. Indeed, as some of the passages quoted in this paper suggest, the fullest crime narratives in the newspapers I have consulted were the descriptions of the executions of serious offenders, descriptions still resonant of the seventeenthcentury mould in which such descriptions were created and from which they had evidently not quite escaped. And above all, I am intrigued by the issue of how the crime reporting of the period fitted in with the much bigger cultural issues identified by Helen Berry. To resolve this issue, we need to think anew about how the various crime narratives of the eighteenth century, in newspapers and elsewhere, were constructed, what impact they may have had on their readers, how they fitted in to the broader concerns of polite society of the period, and what was the nature of the language in which they were couched. The new ways of writing crime enshrined in the provincial newspaper will surely best be understood in the broader context of the culture in which they were created.

\author{
James J. Sharpe \\ Department of History \\ University of York \\ Vanbrugh College V/136 \\ Heslington \\ UK - York YO10 5DD \\ history-enquiries@york.ac.uk
}

case had been published. It would be interesting to search comparable eighteenth-century materials for similar evidence: Pepys (2003, vol. 5, p. 8-9, 10-11, 13, 17, \& 23). For a clear demonstration of how detailed memories of crime could survive in oral culture, see Gough (1981).

78 Langbein (1983, pp. 97-120).

79 The unresolved nature of this problem is demonstrated by Landau's assertion that, on her analysis, the elite and possibly other citizens of London had considerable first-hand experience of crime, and got their information on the subject from this experience rather than reading the newspapers: (2010, especially pp. 396-397 \& 417).

80 A point central to Snell's interpretation, e.g. (2005b, p. 50); cf. Foyster's comment that "the hapless victim of crime, rather than the criminal, became the central figure in these narratives" : (2007, p. 10).

81 Indeed, Devereaux traces an emergent fear of what was to be identified as the criminal class in the late eighteenth-century newspapers he analyses: (2007, p. 19). 


\section{REFERENCES}

\section{Manuscript Sources}

(All held at The National Archives (TNA), London).

Clerks of Assizes, Northern Circuit:

Indictment Files: ASSI 44/91 Part 1 (1777); ASSI 44/92 Part 2 (1778).

Minute Book: ASSI 41/7, Northern Circuit Crown Minute Book 1775-1788.

Palatinate of Chester, Court of Great Sessions.

Gaol Files: CHES 24/157/4 Winter 1732; CHES 24/161/3 Winter 1742.

\section{Newspapers}

Adams's Weekly Courant:15 November 1738; 11 September 1750; 26 May 1771; 3 September 1771; 7 September 1790; 8 March 1791; 26 April 1791.

The Chester Chronicle: 14 March 1775; 6 September 1776.

The York Courant: 31 December 1728; 10 April 1739; 8 July 1740; 27 October 1741; 11 August 1767; 18 March 1777; 10 April 1781; 6 November 1781; 26 January 1787; 20 March 1787; 19 January 1790; 23 February 1790; 10 August 1790; 13 August $1790 ; 31$ August 1790; 7 September 1790; 9 November 1790; 21 December 1790; 21 January 1793; 6 February 1797; 13 February 1797; 20 February 1797.

\section{Other Printed Works}

Anon., The whole trial of Mr Josiah Fearn, of Leeds, in the county of York, for the murder of Mr Thomas Grave, at the assizes held at the castle of York, on Friday, the $10^{\text {th }}$ of March, 1748, York, 1748.

Anon., The trial, conviction, confession and execution of William Smith, for poisoning his father-in-law, Thomas Harper, and William and Anne Harper his children, of Ingleby Manor in Yorkshire, by mixing arsenic in a Good-Friday cake, who was tried on Monday the $13^{\text {th }}$ of August at the assizes held in the castle of York, London, 1753.

Anon., The trial at large of John Bolton. Gent., of Bulmer, near Castle Howard, for the wilful murder of his apprentice girl, Elizabeth Rainbow, on Sunday the 21 ${ }^{\text {st }}$ of August, 1774, York, 1774.

Anon., A calendar of the felons and other malefactors, now confined in his majesty's gaol the castle of York, for what, and by whom committed, in order to take their trials at the assizes, to be holden for the county of York on Saturday the $9^{\text {th }}$ day of March 1776, York, 1776.

Barker, H., Press, politics and opinion in eighteenth-century England, Oxford, Oxford University Press, 1998.

Barker, H., Newspapers, politics and English society, Harlow, Longman, 2000.

Barker, H., England 1760-1815, in Barker, H., and Burrows, S., (eds.), Press, politics and the public sphere in Europe and North America, Cambridge, Cambridge University Press, 2002, pp. 93-112.

Berry, H., Promoting taste in the provincial press: national and local culture in eighteenthcentury Newcastle-upon-Tyne, British Journal for Eighteenth-Century Studies, 2005, 25, pp. 1-17.

Black, J., The English press in the eighteenth century, Beckenham, Croom Helm, 1987.

Campbell, R., Sentence of death by burning for women, Journal of legal history, 1984, 5, pp. 44-59. 
Clarke, R., From Grub Street to Fleet Street: an illustrated history of English newspapers 1750-1859, Aldershot, Ashgate, 2004.

Cranfield, G.A., The development of the provincial newspaper 1700-1760, Oxford, Oxford University Press, 1962.

Cranfield, G.A., The press and society from Caxton to Northcliffe, London, Longman, 1978.

Curtiss, L.P., Jack the Ripper and the London Press, New Haven, Yale University Press, 2002.

Davies, R., A memoir of the York press: with notices of authors, printers and stationers, in the sixteenth, seventeenth and eighteenth centuries, Westminster, 1868.

Devereaux, S., The abolition of the burning of women in England reconsidered, Crime, histoire \& sociétés/ Crime, History, Societies, 2005, 9, pp. 73-98.

Devereaux, S., From sessions to newspaper? Criminal trial reporting, the nature of crime, and the London press, 1770-1800, The London Journal, 2007, 32, pp. 1-27.

Dickinson, J.R., \& Sharpe, J.A., Infanticide in early modern England: the Court of Great Sessions at Chester, 1650-1800, in Jackson, M. (ed.), Infanticide: historical perspectives on child murder and concealment, Aldershot, Ashgate, 2002, pp. 35-51.

Dindor, Z., Death recorded: capital punishment and the press in Northampton, 1780-1834, Midland History, 2008, 33, pp. 179-195.

Ellis, J., Urban conflict and popular violence: the Guildhall riots of 1740 in Newcastle-uponTyne, International Review of Social History, 1980, 25, pp. 333-349.

Ferdinand, C.Y., Benjamin Collins and the provincial newspaper trade in the eighteenth century, Oxford, Oxford University Press, 1997.

Forshaw, C.F. (ed.), Holroyd's collection of Yorkshire ballads: with some remarks on ballad lore by W.J. Kaye, London, 1892.

Fox, A., Oral and literate culture in England 1500-1700, Oxford, Oxford University Press, 2000.

Foyster, E., Introduction: newspaper reporting of crime and justice, Continuity and Change, 2007, 22, pp. 9-12.

Fumerton, P., Guerrini, A., \& McAbee, K. (eds.), Ballads and broadsides in Britain, 15001800, Aldershot, Ashgate, 2010.

Gatrell, V.A.C., The hanging tree: execution and the English people 1770-1868, Oxford, Oxford University Press, 1994.

Gough. R., The History of Myddle, ed. Hey, D., Harmondsworth, Penguin, 1981.

Gretton, T., Murders and moralities: the English catchpenny press 1800-1860, London, Colonade, 1980.

Ingledew, C.J. Davison, The ballads and songs of Yorkshire: transcribed from private manuscripts, rare broadsides, and scarce publications, London, 1860.

Jackson, M., New-born child murder: women, illegitimacy and the courts in eighteenthcentury England, Manchester, Manchester University Press, 1996.

King, P., Newspaper reporting, prosecution practice and perceptions of urban crime: the Colchester crime wave of 1765, Continuity and Change, 1984, 2, pp. 25-58.

King. P., Newspaper reporting and attitudes to crime in late eighteenth- and early nineteenthcentury London, Continuity and Change, 2007, 22, pp. 73-112.

King, P., Making crime news : newspapers, violent crime and selective reporting of Old Bailey trials in the late eighteenth century, Crime, histoire \& sociétés/ Crime, History, Societies, 2009, 13, pp. 99-116.

Landau, N, Gauging crime in late eighteenth-century London, Social History, 2010, 35, pp. 396-417.

Langbein, J.H., Albion's Fatal flaws, Past and Present, 1983, 98, pp. 97-120. 
Linebaugh, P., The Tyburn riot against the surgeons, in Hay, D., et al. (Eds), Albion's fatal tree: crime and society in eighteenth-century England, Harmondsworth, Penguin, 1977, pp. 65-118.

McMillan, R., Representations of crime in the eighteenth century: a study of north eastern newspapers (unpublished MA dissertation) University of York, 2006.

McMahon, V., Murder in Shakespeare's England, London, New York, Hambledon, Palgrave, Macmillan, 2004.

Morgan, G., Rushton, P., Print culture, crime and transportation in the criminal Atlantic, Continuity and Change, 2007, 22, pp. 49-71.

Newton, D., Smith, M., The Stamford Mercury: three centuries of newspaper publishing, Stamford, Shaun Tyas, 1999.

Oldham, J., Law reporting in the London, newspapers, 1756-1786, American Journal of Legal History, 1987, 31, pp. 177-206.

Pepys, S., The complete diary of Samuel Pepys, eds. Latham, R., and Matthews, W., 11 vols., London, Harper Collins, 2003.

Shoemaker, R.B., The Old Bailey proceedings and the representation of crime and criminal justice in eighteenth-century London, Journal of British Studies, 2008, 47, pp. 559-580.

Snell, E., Perceptions of violent crime in eighteenth-century England: a study of discourses of homicide, aggravated larceny and sexual assault in the eighteenth-century newspaper, (unpublished PhD thesis) University of Kent at Canterbury, 2005.

Snell, E., Representations of criminality and victimisation in provincial newspapers: 'The Kentish Post' 1717 to 1768, Southern History, 2005, 27, pp. 48-75.

Snell, E., Discourses of criminality in the eighteenth-century press: the representation of crime in 'The Kentish Post' 1717-1768, Continuity and Change, 2007, 22, pp. 13-47.

Styles, J., Print and policing: crime advertising in eighteenth-century provincial England', in Hay, D., Snyder, F. (eds.), Policing and Prosecution in England 1750-1859, Oxford, Oxford University Press, 1989, pp. 55-112.

Williamson, W., The trials at large of the felons in the castle of York, at the Lammas assizes, 1775, York, 1775.

Williamson, W., The trials at large of the felons at the castle of York, at the Lent assizes, 1776, York, 1776a.

Williamson, W., The trials at large of the felons in the castle of York at the Lammas assizes, 1776, York, 1776b.

Williamson, W., The trials at large of the felons in the castle of York at the Lent assizes, 1777, York, 1777. 